
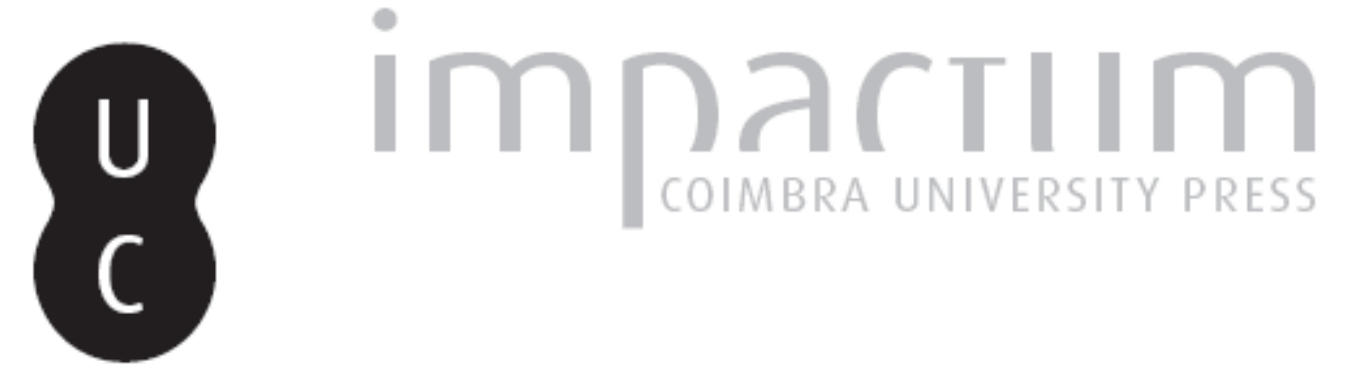

\title{
A Revolução Francesa na perspectiva de um diplomata português: (a correspondência ofical de Antonio de Araújo de Azevedo)
}

Autor(es): Pintassilgo, Joaquim

Publicado por: Imprensa da Universidade de Coimbra

URL persistente:

URI:http://hdl.handle.net/10316.2/43766

DOI:

DOI:https://doi.org/10.14195/2183-8925_10_7

Accessed : $\quad$ 26-Apr-2023 10:42:41

A navegação consulta e descarregamento dos títulos inseridos nas Bibliotecas Digitais UC Digitalis, UC Pombalina e UC Impactum, pressupõem a aceitação plena e sem reservas dos Termos e Condições de Uso destas Bibliotecas Digitais, disponíveis em https://digitalis.uc.pt/pt-pt/termos.

Conforme exposto nos referidos Termos e Condições de Uso, o descarregamento de títulos de acesso restrito requer uma licença válida de autorização devendo o utilizador aceder ao(s) documento(s) a partir de um endereço de IP da instituição detentora da supramencionada licença.

Ao utilizador é apenas permitido o descarregamento para uso pessoal, pelo que o emprego do(s) título(s) descarregado(s) para outro fim, designadamente comercial, carece de autorização do respetivo autor ou editor da obra.

Na medida em que todas as obras da UC Digitalis se encontram protegidas pelo Código do Direito de Autor e Direitos Conexos e demais legislação aplicável, toda a cópia, parcial ou total, deste documento, nos casos em que é legalmente admitida, deverá conter ou fazer-se acompanhar por este aviso.

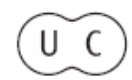


REVISTA DE HISTORIA DAS IDEIAS IO
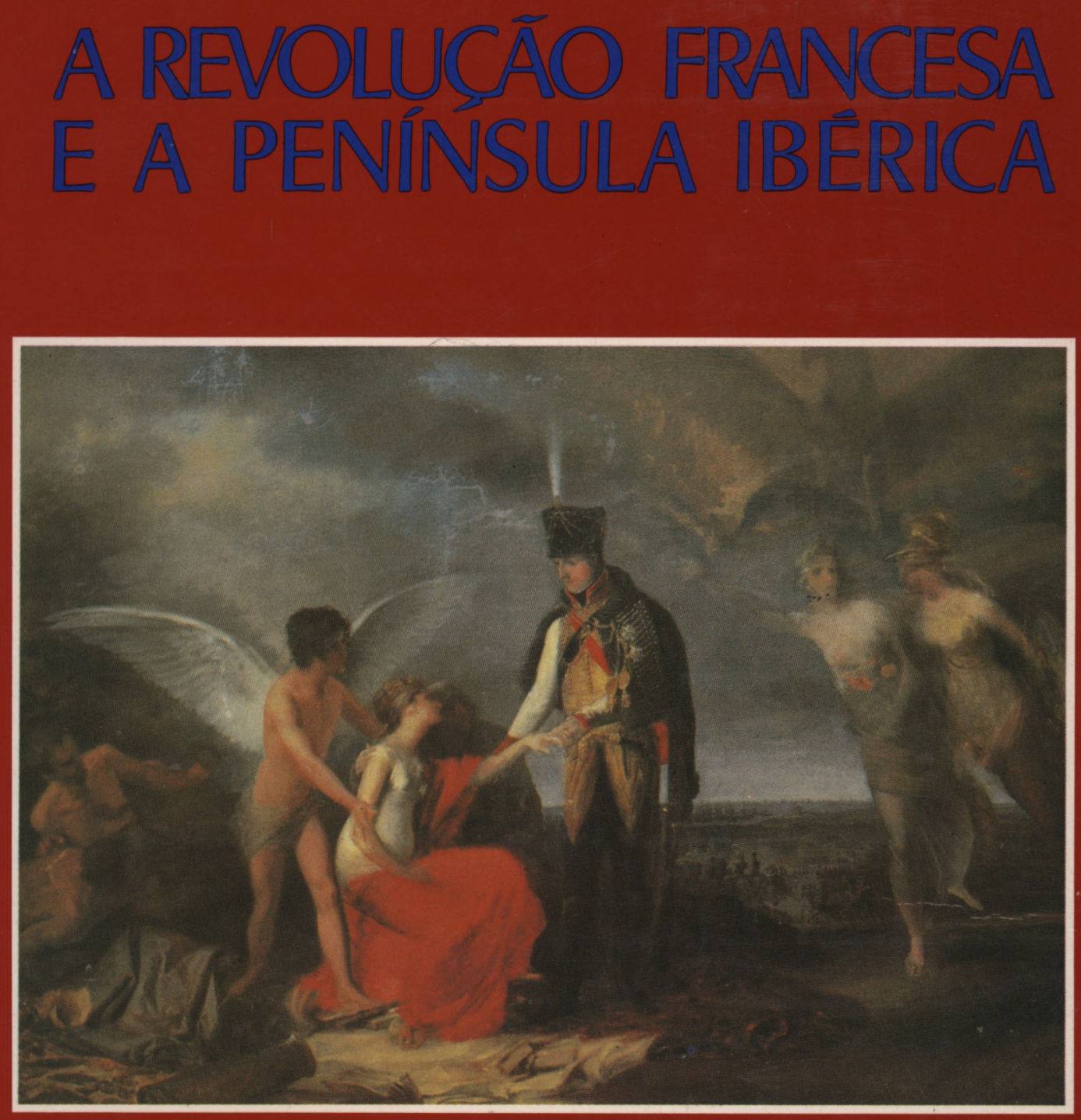

INSTITUTO DE HISTÖRIA E TEORIA DAS IDEIAS FACULDADE DE LETRAS 
JOAQUIM PINTASSILGO *

\title{
A REVOLUÇÃO FRANCESA NA PERSPECTIVA DE UM DIPLOMATA PORTUGUES
}

\author{
(A correspondência oficial de \\ António de Araújo de Azevedo)
}

Durante muito tempo teve-se como uma evidência histórica a oposição que, desde o seu início, os dirigentes políticos portugueses teriam manifestado para com os acontecimentos da Revclução Francesa; seria, desse ponto de vista, a reaç̧ão natural de um regime absolutista europeu à tentativa para se implantar naquele país um regime liberal.

Alguns estudos têm contribuído para desmistificar esta ideia. De entre eles não quero deixar de destacar, pela sua utilidade, a tese de licenciatura - apresentada a esta Faculdade de Maria Aquila Neves dos Santos intitulada Pré-revolução $e$ revolução em França (1788-1789): a óptica do embaixador Sousa Coutinho $\left({ }^{1}\right)$. Neste trabalho a autora demonstra, a partir da análise da correspondência diplomática de $\mathrm{D}$. Vicente de Sousa Coutinho. como este diplomata havia manifestado o seu contentamento por muitas das medidas tomadas pela Assembleia Nacional Constituinte durante o ano de 1789, chegando ao ponto de recomendar a sua aplicação em Portugal. Paralelamente, a Gazeta de Lisboa, como a autora também refere, não deixava de incluir notícias favoráveis às transformações operadas em França. Já foi sublinhado, noutro lugar $\left(^{2}\right)$, a relativa simpatia com que Luis Pinto de Sousa Coutinho (o futuro Visconde de Balsemão), então Secretário de Estado dos Negócios Estrangeiros e da Guer-

* Escola Superior de Educação de Castelo Branco.

(1) Maria Áquila Neves dos Santos, Pré-revolução e revolução em França (1788-1789). A óptica do Embaixador Sousa Coutinho. Dissertação de licenciatura em História, apresentada à Faculdade de Letras aa Universidade de Coimbra, Coimbra, 1970.

(2) Cf., por exemplo, Joaquim Veríssimo Serrão, História de Portugal, Vol. VI - O despotismo iluminado (1750-1807), Lisboa, Editorial Verbo. 1982, p. 132. 


\section{Revista de História das Ideias}

ra, se referiu aos mesmos acontecimentos. E natural que outros elementos da «élite» política da época perfilhassem, no início, idêntica opinião.

Este facto deixará de nos parecer estranho se atentarmos no seguinte: ao contrário do que se admitiu durante bastante tempo, o reinado de D. Maria I e a fase inicial da regência do Príncipe D. João surgem como um dos momentos altos do absolutismo reformista em Portugal, o que implica, na nossa opinião, o abandono (ou pelo menos a relativização) da concepção ideológica de "viradeira». Embora com algumas alterações, a política reformista herdada do pombalismo, longe de ser abandonada é prosseguida. Entre o "pessoal» político da época encontramos muitos homens cultos, competentes e sensíveis às novidades do «Século»; recordemos aqui nomes como os de José de Seabra da Silva, do Duque de Lafões, de D. Rodrigo de Sousa Coutinho ou do próprio António de Araújo de Azevedo, que é alvo deste nosso estudo. Aliás, durante a penúltima década do Século XVIII instala-se um certo clima de tolerância e de amplas iniciativas práticas tendentes a remover os obstáculos ao desenvolvimento económico do país, clima e iniciativas essas que deram origem, por exemplo, à fundação da Sociedade Económica de Ponte de Lima є da Real Academia das Ciências de Lisboa. Toda esta problemática nos mereceu uma reflexão um pouco mais detalhada noutro lugar $\left({ }^{3}\right)$, pelo que não a iremos agora aprofundar.

Ora acontece que é exactamente nesta perspectiva reformista que são interpretados os primeiros acontecimentos da Revolução Francesa; inicialmente acredita-se em Pcrtugal que apenas serão introduzidas algumas reformas na monarquia francesa de modo a melhorar a sua funcionalidade, mas sem pôr em causa o essencial e, em especial, a autoridade do monarca; no fundo era o que muitos dos nossos homens públicos desejavam que acontecesse em Portugal. É essa a razão da simpatia inicial.

Essa posição vai, no entanto, começar a mudar. A partir do início de Setembro de 1789 a Gazeta de Lisboa suspende o seu noticiário de França. Não sabemos ao certo quais os acontecimentos revolucionários que terão ditado essa mudança de atitude. Seriam as repercussões do «Grande Medo»? Das medidas tomadas na famosa noite do «4 de Agosto»? Da aprovação da Declaração dos Direitos do Homem?

(3) Cf. Joaquim Pintassilgo. $O$ «absolutismo esclarecido» em Portugal: inovações, polémicas e alinhamentos (final do Séc. XVIII-início do Séc. $X I X)$. Comunicação apresentada ao Seminário «Do Antigo Regime ao Liberalismo (1750-1850) - perspectivas de síntese» organizado pela Cooperativa de Estudos e Documentação (a publicar). 
Entretanto, D. Vicente de Sousa Coutinho continua a manifestar uma concordância geral em relação a muitas das medidas tomadas, embora um certo desencanto comece a penetrar o seu pensamento; preocupa-o, em especial, o receio de que a «anarquia» se instale entre o Povo. Para o final do ano as dúvidas adensam-se e o nosso embaixador, segundo Maria Áquila Neves dos Santos, «já não sabia se tal havia sucedido para bem ou para mal daquela monarquia» $\left({ }^{4}\right)$. E pena que esta historiadora tenha concluído a sua análise em Dezembro de 1789 e não se tenha debruçado sobre a correspondência relativa ao ano de 1790 e seguintes para se concluir qual o ponto de viragem na posição de D. Vicente que, recordêmo-lo, morreu no seu posto em Maio de 1792.

E, no entanto, certo que já antes as autoridades portuguesas haviam começado a tomar consciência de que não estavam perante simples reformas da monarquia francesa, mas antes perante uma verdadeira subversão das suas estruturas. cia que as levará para o campo da oposição declarada à Revolução. É, pois, a radicalização do processo revolucionário francês, associada ao temor que se instala entre os grupos dirigentes portugueses pela propagação dos princípios revolucicnários, que vai conduzir à posição contra-revolucionária, tornada predominante entre a «élite» política portuguesa.

Feita esta introdução de carácter genérico, precisemos um pouco melhor o objectivo da presente comunicação. Foi nossa intenção estudar a forma como outro personagem de destaque na época, e de alguma forma ligado aos acontecimentos, encarou o evoluir da Revolução Francesa; incidiu a nossa escolha sobre António de Araújo de Azevedo (o futuro Conde da Barca), cujas ideias políticas e económicas estamos a estudar no âmbito de uma Dissertacão de Mestrado $\left(^{5}\right)$. Da referida análise partimos para a definição de alguns contornos do seu pensamento político.

$E$, no fundo, uma tentativa de observar sob um novo prisma a tradicional documentação da história diplomática; rendemos aqui a nossa homenagem, não só à tese de licenciatura já destacada, mas igualmente a outro trabalho, já antigo, mas bastante estimulante; refiro-me à obra As impressões de um diplomata português na Côrte de Berlim da autoria de António Ferrão ( $\left.{ }^{6}\right)$.

(4) Maria Aquila Neves dos Santos, ob. cit., p. 250.

(5) Dissertação de Mestrado a apresentar à Faculdade de Ciências Sociais e Humanas da Universidade Nova de Lisboa e que está a ser orientada pelo Prof. Dr. José Esteves Pereira.

$\left.{ }^{(}\right)$António Ferrão (Pref., Intr. e Notas), As impressões de um diplomata português na Corte de Berlim. Correspondência oficial de 
Recordemos brevemente o trajecto de António de Araújo de Azevedo durante este período. Data de 1787 a sua nomeação como Enviado Extraordinário e Ministro Plenipotenciário de Portugal nas Províncias Unidas dos Países Baixos, mas é apenas em Junho de 1789 que ele deixa Lisboa; após uma viagem de cerca de um ano, repartida entre a Inglaterra e a própria França, no dia 4 de Agosto de 1790 o nosso diplomata chega finalmente a Haia. Suspenderemos a nossa análise, no que a esta comunicação diz respeito, em 1796, ano em que Araújo é nomeado para, em Paris, tentar negociar um tratado de paz com a França.

São muito escassas as referências de António de Araújo de Azevedo à Revolução Francesa nos poucos ofícios que envia durante a sua viagem por Inglaterra e França; daí que não nos seja possível verificar qual a evolução da sua posição durante o ano de 1789. Desde Junho desse ano que ele percorre atentamente a Inglaterra, deslumbrado com as suas realizações industriais lestamos, é bom não esquecer, em pleno período de "arranque» da Revolução Industrial). E no início de 13 de Outubro de 1789, enviado de Londres, que ele fala pela primeira vez da França:

«Logo que a minha saúde mo permita passarei daqui directamente para Holanda, pois que as desordens políticas de França apresentam uma cena tão horrorosa, que deixo de aproveitar-me da licença que Sua Magestade me tinha concedido para passar por aquele Reino, esperando para o futuro uma melhor conjuntura» ( 7$)$.

Em Outubro de 1789 a posição de Araújo em relação à Revolução Francesa é já, pois, bastante crítica, o que está de acordo com o cesaparecimento dos artigos relativos a esse assunto das páginas da Gazeta de Lisboa, embora um pouco em desacordo com a que, de Paris, D. Vicente continuava a manter.

Araújo havia dito, como vimos, que desistia do seu projecto de passar pela França; mas a curiosidade irá vencer os seus receios. Em ofício de 26 de Março de 1790 D. Vicente de Sousa Coutinho dá-nos conta da chegada a Paris de António de Araújo e de D. Domingos de Sousa Coutinho $\left(^{(8)}\right.$. Nos cerca de quatro

D. Alexandre de Sousa e Holstein, primeiro ministro de Portugal na Côrte da Prússia, no tempo de Frederico-Guilherme II (1789-1790), Coimbra, Imprensa da Universidade, 1919.

(7) Arquivo Nacional da Torre do Tombo. Arquivo do Ministério dos Negócios Estrangeiros. Legação de Portugal nos Países Baixos. Caixa n. 15.

(8) Idem. Legação de Portugal na França, Caixa n.o 16, Ofício n.。 1722 de D. Vicente de Sousa Coutinho para Luis Pinto de Sousa Coutinho. 


\section{A Perspectiva de um Diplomata Português}

meses que permaneceu nessa capital o nosso diplomata teve oportunidade de conhecer, segundo um seu biógrafo $\left({ }^{9}\right)$, personalidades políticas como Montmorin, Necker, Bailly ou cientistas e literatos como Lavoisier, Fourcroy, Lallande, o Abade Delille e Marmontel entre outras; para além disso, terá assistido a algumas sessões da Assembleia Nacional. A partir desta altura um misto de atracção e repulsa pela França coeva parece instalar-se no seu pensamento.

Neste momento uma verdadeira concordância de pontos de vista estabelece-se entre ele e o nosso embaixador em Paris. Escreve este último, em Abril, a Luis Pinto o seguinte:

"Nesta semana passei dois dias no campo com o nosso ministro que vai a Haia e com o maior prazer de não ouvir falar, naquele curto espaço de tempo, da Assembleia e dos seus debates. Confesso a V. Ex.a que fiquei encantado da sua instrução, do seu juizo e da sua índole» $\left({ }^{(10)}\right.$.

D. Vicente aproveita, inclusive, para propôr Araújo para a Legação de Londres. A sua posição acerca dos acontecimentos a que assiste já é menos optimista que no ano anterior; no dia 28 de Julho de 1790 diz ele:

«Daqui partiram hoje os dois ministros da Haia e de Copenhaga, $e$ não perderão o tempo que se detiveram nesta Corte, vendo e examinando, na grande cena que se representa nela, os delírios do espírito humano e a revolução de um tamanho império» (11).

$\mathrm{Na}$ correspondência oficial que vai manter a partir do momento em que se instala em Haia (onde chega a 4 de Agosto de 1790) António de Araújo vai ser, felizmente para nós, muito mais regular e prolixo.

Chegados aqui, façamos um breve interlúdio na nossa análise para sublinhar a seguinte questão que representa, no fundo, a nossa hipótese de trabalho: com a radicalização da Revolução Francesa, mesmo personagens esclarecidos e reformadores como é, inegavelmente, o caso de António de Araújo de Azevedo -,

(9) Cf. Sebastião Francisco de Mendo Homem de Magalhães Trigoso, "Elogio Histórico do Conde da Barca' recitado na Assembleia da República de 24 de Junho de 1819....», in História e Memórias da Academia Real das Ciências de Lisboa, Tomo VIII, Parte II, pp. XV-XLVI, Lisboa, 1823.

(10) Legação de Portugal na França, Caixa n. 16 , Ofício de D. Vicente de Sousa Coutinho, Paris, 29 de Abril de 1790.

(11) Idem, Ofício n. 24, Paris, 28 de Julho de 1790. 


\section{Revista de História das Ideias}

que inicialmente haviam demonstrado alguma simpatia pelo processo, são conduzidos para o campo ideológico anti-revolucionário (ainda que numa perspectiva de moderação). $\mathrm{Na}$ verdade, alguns meses bastaram para eles tomarem consciência de que os acontecimentos não evoluiam no sentido de uma monarquia reformada, mas sim num sentido bastante mais subversivo e incontrolável. A simpatia despertada aquando da convocação do «Estados Gerais» havia sido já totalmente alienada.

Debrucemo-nos então, mais directamente, sobre os ofícios de António de Araújo enviados de Haia e sobre as opiniões acerca da Revolução Francesa aí manifestadas. Chamemos só a atenção para o seguinte: os seus textos não evidenciam grandes preocupações doutrinárias; escritos «em cima» dos acontecimentos, representam antes uma reacção emotiva aos mesmos; mesmo assim, está-lhes subjacente um determinado pensamento político que procuraremos delimitar.

Um dos temas fortes do seu discurso anti-revolucionário é o da «anarquia». Espírito reformador, mas de um reformismo que não punha em causa a ordem estabelecida, antes a procurava aperfeiçoar, o futuro Conde da Barca teria forçosamente que se atemorizar com a derrocada da sociedade tradicional a que assistia em França. Diz ele: "Os vícios da Constituição francesa perpetuam os estragos da anarquia» ${ }^{(2)}$. Várias outras referências deste género podemos encontrar; já $\mathrm{D}$. Vicente demonstı ara idêntica preocupação. Por outro lado, a consciência de que a Revolução Francesa teria subvertido totalmente a normalidade política da Europa surge, por exemplo, na seguinte passagem: «....o quanto a revolução de França tem subvertido o sistema político da Europa» $\left({ }^{13}\right)$.

Outro dos temas com uma grande presença é o que surge representado pelas seguintes expressões: «despotismo», «tirania», «ditadura» e «opressão» entre outros. Homem de uma certa formação «iluminista», mais dado à tolerância e à moderação do que aos «extremos», defensor de uma maior abertura social $\left({ }^{14}\right)$, mas no interior dos quadros de uma sociedade aristocrática e de um poder monárquico forte, é natural que Araújo considere que

(12) Legação de Portugal nos Países Baixos, Caixa n.o 16. Ofício n.. 93 de António de Araújo de Azevedo para Luis Pinto de Sousa Coutinho.

(13) Idem, Ofício n. 104.

(14) Cf. Carta de um Vassalo Nobre ao seu Rei e duas respostas à mesma.... Lisboa, 1820. A primeira resposta foi atribuída a António de Araújo de Azevedo. 
o pior dos «despotismos» é o «despotismo democrático» ${ }^{\left({ }^{15}\right)}$. Vejamos mais algumas das suas afirmações: «....um Povo tiranizado pelo mais bárbaro despotismo que tem afligido a espécie humana» ${ }^{(1)}$ ). Ou então: «.... se não houver uma explosão interior da França contra a tirania que a domina; é para admirar que os excessos da opressão não tenham ainda produzido esse efeito» $\left({ }^{17}\right)$. Noutro momento ele critica aquilo a que chama os «Ecessos da democracia» $\left.{ }^{18}\right)$. O que podemos concluir é que a «democracia» e a «igualdade» são princípios que não fazem parte do seu quadro mental. Embora noutro contexto, é convincente a seguinte frase:

"Cada vez aumenta mais a discórdia nas Províncias Bélgicas e a animosidade contra os franceses pelo Despotismo que estes pretendem exercer introduzindo a sua nivelação democrática» (19).

Vejamos agora qual a concepção de «Povo» expressa pelos seus textos. O Povo de Paris, em particular, não surge muito favorecido nas referências de Araújo; este apresenta-o como sendo «um Povo incendiado com a paixão cega e turbulenta da liberdade» $\left({ }^{20}\right)$; da Nação francesa, no seu conjunto, o seu parecer não é mais elogioso: «Deve-se temer todo o género de audácia de uma Nação dominada por um delírio frenético» ${ }^{(21)}$. Falando do Povo dos Países Baixos austríacos, também revoltado, António de Araújo já havia manifestado opiniões concordantes com aquelas; senão vejamos: «a vontade daqueles Povos para a rebelião» $\left.{ }^{22}\right)$. Ou então: «....porque o Povo é sempre mais fácil de iludir que de desenganar....» (23). Aqui, o autor chama já a atenção para uma das ideias que lhe vai ser cara: a da instrumentalização do Povo; este, não é o inspirador dos tumultos (para os quais é, no entanto, propenso por natureza...), é antes conduzido e manipulado pelos que ele apelida de «facciosos» e «demagogos»; ilustremos com exemplos do próprio autor: «....onde não seria dominada pelos facciosos que ก1. 93.

(15) Legação de Portugal nos Países Baixos, Caixa n. 16 , Ofício

(16) Idem, Caixa n. 17 , Ofício n. 228.

(17) Idem, Ofício n. 217.

(18) Caixa n.o 16, Ofício n. 85.

(19) Caixa n. ${ }^{\circ} 17$, Ofício n. 166.

(20) Caixa n.॰16. Ofício n. ${ }^{\circ} 141$.

(21) Idem. Ofício n. 156.

(22) Idem, Ofício n.o 100 .

(23) Caixa n. 15 , Ofício n.॰ 16. 
suscitam a Plebe para a perpetração dos seus projectos criminosos» $\left({ }^{24}\right)$. Aliás, o próprio povo surge como uma vítima: «a tirania que sofre (aquele Povo) debaixo das facções democráticas» ${ }^{25}$ ). Temos que reconhecer que a sua concepção de Povo - a qual, por comodidade, poderemos apelidar de «aristocrática» - não deixa de se adequar às posições por ele defendidas - e já por nós analisadas - contra o chamado «despotismo democrático».

À medida que o tempo vai passando e que Araújo se sente cada vez mais distante do caminho que toma a Revolução, a sua linguagem vai-se tornando cada vez mais agressiva e os adjectivos utilizados gradualmente mais contundentes. Em 30 de Dezembro de 1790 , em carta dirigida ao Marquês de Ponte de Lima, no final de um ano marcado principalmente pela aprovação da Constituição Civil do Clero, António de Araújo refere-se à Revolução como sendo a «loucura francesa» $\left({ }^{26}\right)$. Em Outubro de 1791, na sequência da abertura da Assembleia Legislativa, diz: «....se a nova Assembleia Nacional continuar tão sinistramente como se anunciou no seu princípio» $\left({ }^{27}\right)$. Os episódios ligados à ocupação das Tulherias e à queda da monarquia conduzem a uma radicalização do seu discurso:

"As horríveis desordens cometidas ultimamente em Paris anunciam a explosão de uma guerra civil» (28).

«Depois da horrorosa catástrofe executada em Paris» (29). "As notícias que chegaram aqui daquela capital são tão horrorosas que seria para desejar a maior brevidade em se aproximarem as forças que subjugassem os fautores atrozes de tantos crimes" $\left({ }^{30}\right)$.

"A situação afrontosa em que se acha El Rei de França e a Família Real» (31).

A 1 de Fevereiro de 1793, já conhecedor da execução de Luís XVI (21 de Janeiro), António de Araújo fala da «horrível catástrofe de El Rei Cristianíssimo e de todos os atentados, injustiças e atrocidades que o precederão» $\left.{ }^{(32}\right)$.

(24) Caixa n. 17 , Ofício n. 186.

(25) Idem, Ofício n. 167.

(26) Caixa n.o 15, Ofício de António de Araújo de Azevedo para o Marquês Mordomo-Mor (30 de Dezembro de 1790).

$\left.{ }^{27}\right)$ Caixa n.॰ 16, Ofício n. 89.

(28) Idem, Ofício n. 135.

(29) Idem, Ofício n. 136.

(30) Idem, Ofício n. 139.

(अ1) Idem, Ofício n. 141 .

(32) Caixa n. 17, Ofício n.॰ 171. 
Os acontecimentos associados à queda dos Girondinos e à tomada do poder pelos Jacobinos vão sendo relatados pelo nosso embaixador em Haia: «Por notícias do interior da França consta que há alguma fermentação tendente a dissolver a Convençãc e substituir outra com uma ditadura» $\left({ }^{33}\right)$. Poucos dias depois: «O povo de Paris está tumultuado desde os últimos dias do precedente mês, porém ignora-se qual seja o partido vencedor» ${ }^{34}$ ); mas em 18 de Junho, referindo que continua «a violência da discórdia entre os partidos da Convenção», dá conta da fuga "de Brissot e de outros elementos da sua facção, assim como dos ministros Rolland e Clarière», ao mesmo tempo que constata que ว «Partido Jacobino» está «dominante em Paris» $\left({ }^{35}\right)$. Dois meses depois, o nosso autor fala das «atrocidades cometidas diariamente» e do «auge de despotismo a que tem chegado a Convenção Nacional» $\left({ }^{36}\right)$. Estamos já, recordêmo-lo, em pleno período do «Terror».

Um momento emocionalmente elevado, na correspondência de Araújo, irá ser atingido aquando da execução da Rainha Maria Antonieta no dia 16 de Outubro de 1793. Dois meses antes já ele antevia os acontecimentos: «a todo o instante se receia a notícia do horrível atentado da sua execuçãos $\left({ }^{37}\right)$. No ofício de 25 de Outubro, recém conhecedor da morte da Rainha, surge-nos a que é, talvez, a tirada mais violentamente anti-revolucionária e dramaticamente apaixonada de António Araújo:

"Não era possível conhecer até à época em que vivemos os excessos de maldade de que os homens são capazes; na série de crimes perpetrados pelos tiranos que governam a França serão para sempre memoráveis as abominações atrozes que inventaram para acusar a infeliz Rainha suoliciada no dia 16 do corrente; a acusação que manifesta com a maior clareza a sua inocência assim como nos acusadores toda a infâmia da calúnia e os desvarios atrozes do espírito humano desprendido da crença da Divindade, dos vínculos da moral e dos sentimentos da humanidade» (38).

Em Julho de 1794, já perto da queda de Robespierre e seus pares, Araújo denuncia a manutenção da Revolução por meio de um «banho contínuo de sangue» $\left.{ }^{39}\right)$. Pouco depois ocorrerá c Golpe de Estado do «9 do Termidor» que não vai merecer, da

(33) Idem, Ofício n. 197.

(34) Idem. Ofício n. 199.

(35) Idem, Ofício n. 200.

(36) Idem, Ofício n.o 212.

(37) Idem, Ofício n. 213.

(38) Idem, Ofício n. 227.

(39) Idem, Ofício n. 267. 


\section{Revista de História das Ideias}

parte do nosso estadista, grandes comentários, talvez por não acreditar que ele trouxesse grandes alterações à vida política francesa.

A posição muito crítica de António de Araújo de Azevedo em face da Revolução Francesa não nos deve levar a simplificações apressadas, quer dizer, à conclusão de que a sua crítica é feita numa perspectiva absolutista tout court, isto é, absolutamente contra-revolucionária. Devemos igualmente ter em conta o «quente» contexto europeu coevo, muito propício ao extremar de posições, deixando pouca margem de manobra para o que ele próprio designa por «meio termo» $\left({ }^{40}\right)$.

$\mathrm{Na}$ carta de 1790 ao Marquês de Ponte de Lima, já por nós referida, diz o nosso diplomata a certa altura:

«Felizmente parece-me que estamos livres de semelhante estrago, porque os desmandos dos legisladores franceses têm sido tão despropositados, que incitam mais os ânimos a detestar o exemplo do que a segui-lo: se fossem mais moderados nas reformas e mais cordatos na construção do edifício da Constituição era temível o contágio" (41).

Mas é nas suas referências aos projectos institucionais para ¿ França, após uma eventual intervenção militar vitoriosa dos "Aliados», que essa não conotação de Araújo com o radicalismo absolutista e contra-revolucionário é mais visível, assim como a sua simpatia por um projecto de um reformismo moderado. Em Agosto de 1792, já a guerra se iniciara e os prussianos pene¿ravam em território francês, admite o nosso diplomata que 0

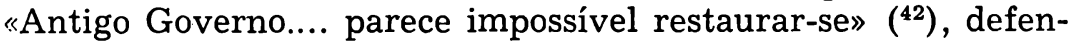
dendo antes uma «mudança na Constituição» ou, como diz no mesmo ofício, «um melhoramento da Constituição». O problema da «ordem e forma de governo que se deve propôr à Nação francesa», segundo as suas palavras, vai continuar a estar no centro das suas preocupações, permanecendo os seus desejos de moderação. Em Setembro de 1792 ele procura precisar um pouco o conteúdo dessa «ordem e forma de governo»:

«a intenção do Imperador e de El Rei da Prússia não é de restabelecer o Antigo Governo, mas de destruir as facções que têm posto a França em uma total anarquia, ameaçando o sossego dos outros Estados da Europa e de dar ao Monarca o grau de autoridade que é conveniente para a pros-

(40) Idem, Ofício n. 186.

(41) Caixa n.॰ 15, Ofício para o Marquês Mordomo-Mor.

(42) Caixa n.o 16, Ofício n. 135. 


\section{A Perspectiva de um Diplomata Português}

peridade daquele reino, fundando a liberdade em principios sólidos e verdadeiros» ( $\left.{ }^{43}\right)$.

Como vemos, Araújo volta a sublinhar a necessidade de não restabelecer o chamado "Antigo Governo» e, além disso, de equilibrar o reforço da autoridade monárquica, de que ele é um inequívoco defensor, com a «liberdade» no seio da população, só que uma liberdade que não resvale para a «anarquia» ou para J que D. Vicente de Sousa Coutinho, com idênticas preccupações, chama de «licença» (ou seja, o «excesso de liberdade», utilizando ainda as suas palavras). Registe-se, no entanto, que Araújo não contesta em abstracto o princípio da «liberdade»; falando da Holanda (já República Bátava, nessa altura) diz ele, a certa altura, demonstrando alguma pena: «Este facto prova que a liberdade de imprensa não está consolidada neste país como em Inglaterra» (44); aqui, curiosamente, a Inglaterra é apresentada como o modelo a esse nível.

Mais tarde, já conhecedor do fracasso «aliado» em Valmy (20 de Setembro), o nosso diplomata responsabiliza por esse resultado principalmente a falta de moderação manifestada no famoso «Manifesto de Brunwick» (25 de Julho); diz ele:

"O que se sabe positivamente é que aquele Chefe (Brunswick), pelo primeiro Manifesto com que rompeu a guerra, alienoı o partido que podia formar em França se deixasse entrever um sistema de moderação, e por este modo sufocou a guerra civil» $\left({ }^{45}\right)$.

E concluindo a sua ideia: «acaba de indispôr os ânimos que desejavam sinceramente a contra-revolução, sem quererem contudo o Antigo Governo».

Em Abril de 1793, pouco depois da revolta do General Dumouriez e referindo-se às suas possibilidades de êxito, Araújo volta à mesma questão: «Se Dumouriez operar a restauração da monarquia, ainda que moderada, com um governo misto...» ( $\left.{ }^{48}\right)$; e no ofício seguinte é ele próprio que sugere a resolução do problema: «....propunhão como estandarte a restauração da Constituição; aclamavão El Rei e formavam nova Convenção em alguma cidade menos populosa do que Paris» $\left({ }^{47}\right)$; é, no fundo, para uma projecto de monarquia constitucional moderada

(43) Idem Ofício $\mathrm{n} \cdot \cdot^{\circ} 141$.

(44) Caixa $n .^{\circ} 18$, Ofício n.॰352.

(45) Caixa n. 16 , Ofício n. ${ }^{\circ} 146$

(46) Caixa n.2 17, Ofício n. 185.

(47) Idem, Ofício $\mathrm{n} .^{\circ} 186$. 
(«à inglesa», eventualmente), que António de Araújo de Azevedo aponta.

Aliás, apesar das muitas críticas feitas por ele à política inglesa, em determinados momentos é nítida uma certa admiração pelo seu sistema constitucional, para além da grande admiração pelo seu avanço industrial. Essa parece-nos ser, até, uma constante entre os diversos representantes do absolutismo esclarecido português.

Recapitulando: restauração da autoridade régia (moderada, sem retorno ao "Antigo Regime»); permanência da Constituição (só que «melhorada»); continuação do funcionamento de uma Assembleia, embora no quadro de um «governo misto»; possibilidade de vigorar uma certa «liberdade». E não nos esqueçamcs de interligar estes dados com as suas críticas ao «despotismo democrático» para podermos começar a vislumbrar qual o modelo de sociedade implícito no discurso anti-revolucionário de António de Araújo de Azevedo. E a conciliação entre «absolutismo» e «liberalismo» que, em certa medida, será concretizada pela «Restauração» de 1814-15.

É sob a mesma perspectiva que o nosso autor interpreta a situação entre os «emigrados» franceses; estes, os seus projectos, as suas divisões internas não entusiasmam António de Araújo; senão vejamos: «Existe discórdia de pareceres entre os emigrantes, porque uns pretendem que se deve intentar o restabelecimento do Antigo Regime e outros que não é justo propôr-se à França mais do que alterações na Constituição» ${ }^{(48)}$; e noutro momento:

«....que não havia nenhum conselho de direcção, mas que
tudo se resolvia pelo tropel e fogo das paixões; que o Conde
d'Artois [irmão de Luís XVI e futuro Carlos X] e ainda
mais facilmente Monsieur [o Conde da Provença. igualmente
irmão de Luís XVI e futuro Luís XVIII], serão convencidos
pelo partido dos moderados. mas que o Príncipe de Condé
era intratável a este respeito e que não admitia proposicão
média entre perecer ov o restabelecimento inteiro do An-
tigo Governo. Tal é a triste situação a que se acha reduzida
uma grande parte da Nobreza de França» $\left({ }^{(4)}\right)$

ou, por fim: «os emigrantes estão separados em três [partidos], o menos importante é o do imediato herdeiro» $\left({ }^{50}\right)$. E ainda na mesma perspectiva que Araújo tenta impedir o embarque do Conde da Provença e do seu séquito para Lisboa, em

(48) Caixa n.•16, Ofício n.` 101.

(49) Idem, Ofício n. 104.

(50) Caixa $n .^{\circ} 18$, Ofício n.e 350. 


\section{A Perspectiva de um Diplomata Português}

busca de "asilo político», assim como desaconselha o reconhecimento da «Regência» por ele proclamada; estas iniciativas do nosso diplomata merecem a aprovação da Côrte portuguesa, como ele próprio reconhece:

"Tenho grande satisfação em saber que o Principe Nosso Senhor aprovara as minhas diligências para suspender o projecto do Viajante [pseudónimo dado ao futuro Luís XVIII na correspondência de Araújo]» ( ${ }^{51}$ ).

Após termos analisado detalhadamente as posições do nosso autor acerca da Revolução Francesa e conhecendo a obra de Edmund Burke Reflections on the Revolution in France, publicada em 1790 e logo traduzida para a língua francesa, não pcdemos deixar de associar as duas perspectivas. Araújo tivesse tomado contacto, desde muito cedo, com esta obra - que, aliás, existia na sua Biblioteca ${ }^{(52}$ - - tendo em conta a grande divulgação que ela teve logo após a sua saída e, além disso, o lugar privilegiado em que o nosso embaixador se encontrava (a Holanda) do ponto de vista das suas possibilidades de actualização bibliográfica. Por outro lado, a sua argumentação não deixa de ter, igualmente, alguns pontos de contacto com a utilizada por aquele pensador político inglês; além disso - não nos esqueçamos - a maioria dos ofícios de Araújo que contêm referências à situação em França são posteriores a 1790. Por fim, não nos parece que haja, no seu pensamento, influências de outro dos importantes doutrinadores contra-revolucionários deste período - o conhecido Abade Barruel ${ }^{(53)}$. Aliás, não só a Histoire du Clergé pendant la Révolution Française é posterior à obra de Burke, como o próprio pensamento do seu autor não se coadunaria facilmente com o reformismo mental de António de Araújo. O nosso diplomata estaria muito mais receptivo a um discurso anti-revolucionário feito, no entanto, a partir de um ponto de vista que é, sem dúvida, liberal, mas de um liberalismo moderado e aristocrático, segundo o modelo do constitucionalismo inglês

(51) Caixa n.० 17, Ofício $n .^{\circ} 171$.

(52) Cf. Bibliotheca Araujiana ou Catalogue des Livres de la Bibliothêque de son Excellence, Monsieur la Commandeur d'Araujo d'Azevedo Envoyé Extra-ordinaire et Ministre Plénipotentiaire de Son Altesse Roiale le Prince Régent de Portugal près de la Cour de Russie. - placée à la maison du bois près de la Haye - en Septembre 1802. et confiée d̀ son très humble serviteur J. D. Nierdt (COD. 1201 da Seç̧ão de «Reservados» da Biblioteca Nacional de Lisboa).

(53) Luís Manuel Reis Torgal, Tradicionalismo e Contra-revolução. o pensamento e a acção de José da Gama e Castro, Coimbra, Universidade, 1973, p. 22. 
e, além disso, respeitador da tradição e das realidades concretas de um país ${ }^{(54)}$.

E chegou o momento de concluirmos esta «comunicação». A ideia que nos foi conduzindo ao longo dela foi a de que, apesar da posição vivamente crítica que vai assumindo em relação ao evoluir da Revolução em França, e que é constatável a partir dos seus ofícios, António de Araújo de Azevedo não abdica do reformismo que já havia guiado a sua participação, por exemplo, na Sociedade Económica de Ponte de Lima e o seu relacionamento com a Academia das Ciências de Lisboa e com os seus mentores. $\mathrm{O}$ extremar de posições, a que a época quase obrigava, não o levou para o campo ideológico-político do tradicionalismo e da contra-revolução.

(54) Cf. Edmund Burke, Reflexions sur la Revolution de France et sur les procédés de certaines sociétés a Londres, relatifs a cet événement (En forme d'une lettre, qui avoit dû être envoyée d'abord du un jeune homme, d Paris), 2:" edição (traduzida da 3." edição inglesa), Londres, 1970. 